\title{
Genotype-Dependent Activity of Tryptophan Hydroxylase-2 Determines the Response to Citalopram in a Mouse Model of Depression
}

\author{
Luigi Cervo, Alessandro Canetta, Eleonora Calcagno, Silvia Burbassi, Giuseppina Sacchetti, Silvio Caccia, \\ Claudia Fracasso, Diego Albani, Gianluigi Forloni, and Roberto W. Invernizzi \\ Istituto di Ricerche Farmacologiche Mario Negri, Department of Neuroscience, 20157 Milan, Italy
}

\begin{abstract}
Polymorphism of tryptophan hydroxylase, the rate-limiting enzyme in the synthesis of brain serotonin (5-HT), is associated with less synthesis of brain 5-HT in DBA/2J and BALB/c than in C57BL/6J and 129/Sv mice. We selected the forced swimming test, a mouse model used to assess the antidepressant potential of drugs, and neurochemical techniques to study strain differences in the response to citalopram, a selective 5-HT reuptake inhibitor. Citalopram reduced immobility time in C57BL/6J and 129/Sv mice but had no such effect in DBA/2J and BALB/c mice. The drug reduced accumulation of 5-hydroxytryptophan (5-HTP), an indicator of 5-HT synthesis, in C57BL/6J and 129/Sv mice but much less in DBA/2J and BALB/c mice. Pretreatment with tryptophan raised 5-HTP accumulation and reinstated the antidepressant-like effect of citalopram in DBA/2J and BALB/c mice, whereas pharmacological inhibition of 5-HT synthesis prevented the effect of citalopram in C57BL/6J and 129/Sv mice. Because there were no strain differences in catecholamine synthesis, locomotor activity, and brain levels of citalopram at the end of the behavioral test, the results suggest that the failure of citalopram to reduce immobility time in $\mathrm{DBA} / 2 \mathrm{~J}$ and $\mathrm{BALB} / \mathrm{c}$ mice is attributable to genotype-dependent impairment of 5-HT synthesis. Interstrain comparisons could probably be a useful strategy for understanding the mechanisms underlying the response to selective serotonin reuptake inhibitors.
\end{abstract}

Key words: antidepressant; serotonin; tryptophan hydroxylase-2; genetic polymorphism; 5-HT synthesis; SSRIs

\section{Introduction}

Antidepressant drugs have greatly improved the outcome of depression. However, a considerable proportion of patients show only a partial or no response, regardless of the treatment received (Thase and Rush, 1995; Stimpson et al., 2002; Fava, 2003). Selective serotonin (5-HT) reuptake inhibitors (SSRIs) are currently the mainstays in the treatment of depression. Pharmacogenetic studies have linked the response to SSRIs to polymorphism in various genes such as those responsible for reuptake, biosynthesis, and metabolism of 5-HT and genes coding for some 5-HT receptor subtypes and signal transduction mechanisms (Serretti and Artioli, 2004).

Tryptophan hydroxylase (TPH)-2, a new isoform of TPH, the rate-limiting enzyme in the biosynthesis of 5-HT, was recently discovered preferentially located in the brain, whereas TPH-1 (formerly TPH) is mainly located in other tissues (Walther et al., 2003). A single nucleotide polymorphism (SNP) of human TPH-2 (G1463A), replacing Arg 441 with His, has been identified (Zhang et al., 2005). Mutation of this gene resulted in a marked

Received Jan. 21, 2005; revised June 29, 2005; accepted July 19, 2005.

The financial support of Ing. P. De Sanctis is greatly appreciated. We thank Dr. M. Carli and Prof. S. Garattini for helpful discussion and J. Baggott for language editing.

Correspondence should be addressed to Roberto W. Invernizzi, Istituto di Ricerche Farmacologiche Mario Negri, Department of Neuroscience, Via Eritrea 62, 20157 Milan, Italy. E-mail: rinvernizzi@marionegri.it. DOI:10.1523/JNEUROSCI.1816-05.2005

Copyright $\odot 2005$ Society for Neuroscience $\quad$ 0270-6474/05/258165-08\$15.00/0 reduction of 5-HT production when the enzyme was expressed in PC12 cells. In addition, the mutant allele in elderly patients with unipolar major depression (10\%) was significantly more frequent than in nondepressed controls (1.4\%) and was associated with a poor response to SSRIs (Zhang et al., 2005).

The gene encoding for TPH-2 shows an SNP (C1473G) that results in the substitution of Pro ${ }^{447}$ with $\mathrm{Arg}^{447}$, with different allelic distribution in different inbred strains of mice (Zhang et al., 2004). DBA/2J and BALB/c mice, homozygous for the allele 1473G, have a lower 5-HT synthesis rate than C57BL/6J and $129 / \mathrm{Sv}$ mice, homozygous for the allele 1473C (Zhang et al., 2004). Therefore, comparison of the effects of SSRIs in these strains may offer a valid animal model to investigate the neurochemical bases of the response to SSRIs.

Several studies have reported marked strain differences in the response to SSRIs in the forced swimming test (FST) (Lucki et al., 2001; David et al., 2003), a procedure widely used to assess the antidepressant potential of drugs in rats and mice (Porsolt et al., $1977,1978)$. However, these studies have given conflicting results, and no firm conclusion can be drawn about the relationship between genotype-dependent differences in 5-HT synthesis and the response to SSRIs.

To address this, we compared the immobility time in the FST in C57BL/6J, 129/Sv, DBA/2J and BALB/c mice under basal conditions and in response to citalopram, the most selective inhibitor of the 5-HT transporter molecule among the SSRIs (Hyttel, 1977; 
Pozzi et al., 1999; Pollock, 2001). Next, we assessed the influence of strain and citalopram on brain 5-HT and catecholamine synthesis rates by measuring the accumulation of 5-hydroxytryptophan (5-HTP) and dihydroxyphenylalanine (DOPA), the immediate precursors of 5-HT and catecholamines, after inhibition of aromatic L-amino acid decarboxylase with m-hydroxybenzylhydrazine (Carlsson et al., 1972; Broadhurst and Briley, 1988). Finally, mice were given the 5-HT precursor L-tryptophan (TRP) or the 5-HT synthesis inhibitor p-chlorophenylalanine (PCPA) (Koe and Weissman, 1966) to assess how treatments that boost or lower 5-HT synthesis affect the citalopram response.

\section{Materials and Methods \\ Animals}

Male C57BL/6J, 129/Sv, DBA/2J, and BALB/c mice (Charles River, Calco, Italy), 6-8 weeks old, were housed five per cage at constant room temperature $\left(21 \pm 1^{\circ} \mathrm{C}\right)$ and relative humidity $(60 \%)$ under a regular light/ dark schedule (light on from 8:00 A.M. to 8:00 P.M.) with food and water available ad libitum. The animals were allowed to adapt to laboratory conditions for at least 1 week. All mice were used only once. Experiments were performed in the daylight, between 10:00 A.M. and 1:00 P.M.

Procedures involving animals and their care were conducted in conformity with the institutional guidelines that are in compliance with national (Decreto Legge number 116, Gazzetta Ufficiale, supplement 40, February 18, 1992; Circolare number 8, Gazzetta Ufficiale, June 14, 1994) and international laws and policies (EEC Council Directive 86/609; NRC, 2003).

\section{Genotyping and PCR conditions}

Genomic DNA was purified from tail snips using a commercial kit (Promega, Milan, Italy). To assess strain genotype, a PCR reaction was done as follows: $94^{\circ} \mathrm{C}, 5 \mathrm{~min}$ (one time), $94^{\circ} \mathrm{C}, 30 \mathrm{~s} ; 62^{\circ} \mathrm{C}, 30 \mathrm{~s} ; 72^{\circ} \mathrm{C}, 30 \mathrm{~s}(40$ times), $72^{\circ} \mathrm{C}, 5 \mathrm{~min}$ (one time). The following primers were used (Zhang et al., 2004): forward, 5' -TTTGACCCAAAGACGACCTGCTTGCA; reverse $\mathrm{C}$-allele specific, $5^{\prime}$-CAGAATTTCAATGCTCTGGTGGG; and reverse G-allele specific, 5'-CAGAATTTCAATGCTCTGGTGGC. For each strain, PCR was done as described using the same forward primer and either the C-allele- or G-allele-specific reverse primer. The expected size of the amplified band was $307 \mathrm{bp}$. PCR products were loaded on $1 \%$ agarose gel and visualized using ethidium bromide staining. All samples were also checked for DNA integrity by PCR amplification of $\beta$-actin gene.

\section{Immobility and locomotor activity}

Forced swimming. The FST was essentially similar to that described previously (Renard et al., 2004). Mice were placed individually in clear Plexiglas cylinders (height, $25 \mathrm{~cm}$; diameter, $10 \mathrm{~cm}$ ) containing $15 \mathrm{~cm}$ of water at $25 \pm 1^{\circ} \mathrm{C}$, and their behavior was videotaped for $6 \mathrm{~min}$. The total period of immobility during the last $4 \mathrm{~min}$ was timed later by two observers who did not know which treatment the mice had received. A mouse was judged to be immobile when it remained floating, in an upright position, making only small movements to keep its head above water. In one experiment, the response to citalopram of C57BL/6J and $\mathrm{DBA} / 2 \mathrm{~J}$ mice was evaluated in a 20 -cm-wide cylinder (height, $40 \mathrm{~cm}$ ) containing $15 \mathrm{~cm}$ of water at $25 \pm 1^{\circ} \mathrm{C}$.

Open field. Separate groups of mice were used to see how treatments reducing immobility in the FST affected locomotor activity. Mice were given citalopram alone or with TRP, as described below (see Drugs and treatments). Thirty minutes after citalopram, they were placed individually in an open field made of gray plastic $(40 \times 40 \mathrm{~cm})$ with the floor divided into 25 equal squares. Spontaneous locomotor activity was measured by counting the number of squares crossed in a 4 min period, corresponding to the behavioral observation time in the FST.

\section{Citalopram measurement}

At the end of the pharmacological test, animals were killed by decapitation, and trunk blood was collected in heparinized tubes and stored at $4^{\circ} \mathrm{C}$ for $1 \mathrm{~h}$. The brain was rapidly removed and stored at $-20^{\circ} \mathrm{C}$ until analysis. Plasma was prepared by centrifugation $(2000 \times g$ for $10 \mathrm{~min}$, at $4^{\circ} \mathrm{C}$ ). Citalopram and its main metabolite $\mathrm{N}$-demethylcitalopram were determined in plasma and brain tissue by HPLC with UV detection (235 $\mathrm{nm})$, according to Grignaschi et al. (1998). The lower limits for quantification (LOQ) were $0.05 \mu \mathrm{g} / \mathrm{ml}$ and $0.08 \mu \mathrm{g} / \mathrm{g}$, using $250 \mu \mathrm{l}$ of plasma or $\sim 200 \mathrm{mg}$ of brain tissue.

\section{Neurochemical studies}

The brain was rapidly excised from the skull and cut along the sagittal line. Half of the brain was immediately frozen on dry ice. The striatum was dissected out from the other half and frozen. Tissue samples were stored at $-80^{\circ} \mathrm{C}$ until analysis. Tissues were homogenized by sonication (output, two to three; $30-35$ pulses with a Branson Sonifier, model 250; Branson Ultrasonic Corporation, Danbury, CT) in 10 vol of ice-cold 0.1 $\mathrm{M} \mathrm{HClO}_{4}$. After centrifugation $\left(4800 \times g\right.$ for $10 \mathrm{~min}$, at $\left.4^{\circ} \mathrm{C}\right)$, the clear supernatant was injected into the HPLC equipped with a $150 \times 3.9 \mathrm{~mm}$ C18 reverse-phase column (Nova-pack; Waters) and coupled to an electrochemical detector (Coulochem II; ESA, Chelmsford, MA). 5-HTP and DOPA were determined in the same sample according to the procedure described previously (Lasley et al., 1984). Brain 5-HT concentrations were determined in separate samples using the same analytical procedure.

\section{Drugs and treatments}

Citalopram hydrobromide (Tocris Cookson, Bristol, UK), dissolved in sterile distilled water, or vehicle was injected intraperitoneally $30 \mathrm{~min}$ before the 6 min FST test. A group of DBA/2J and BALB/c mice pretreated intraperitoneally with $300 \mathrm{mg} / \mathrm{kg}$ TRP (Fluka, Buchs, Switzerland) or vehicle was injected with citalopram $(5 \mathrm{mg} / \mathrm{kg})$ or vehicle $30 \mathrm{~min}$ later, and immobility in the FST was evaluated $30 \mathrm{~min}$ after the last injection. A group of C57BL/6J and 129/Sv mice was given $100 \mathrm{mg} / \mathrm{kg}$ PCPA (Sigma-Aldrich, Milan, Italy) or vehicle orally for 3 consecutive days. Twenty-four hours after the last dose, they were given $5 \mathrm{mg} / \mathrm{kg}$ citalopram or vehicle, and, 30 min later, their immobility was evaluated in the FST. Brain and plasma levels of citalopram and its main metabolite were measured in the same mice at the end of the behavioral test.

Separate groups of mice were used to evaluate the effects of treatments on 5-HTP and DOPA accumulation after inhibition of aromatic L-amino acid decarboxylase with $m$-hydroxybenzylhydrazine (Carlsson and Lindqvist, 1978), injected (100 mg/kg, i.p.) $0.5 \mathrm{~h}$ after citalopram; mice were killed by decapitation 30 min later.

The solutions were freshly prepared immediately before use and injected in a volume of $10 \mathrm{ml} / \mathrm{kg}$. Doses of citalopram and $m$-hydroxybenzylhydrazine were referred to the respective salts. Doses of PCPA and TRP were calculated as free bases.

\section{Statistics}

To determine whether basal immobility time, locomotor activity, accumulation of brain 5-HTP and DOPA, and brain levels of 5-HT differed between strains, data were analyzed by one-way ANOVA, followed by Tukey-Kramer's test or by Student's $t$ test. The effects of vehicle and 2.5 and $5 \mathrm{mg} / \mathrm{kg}$ citalopram on immobility time and the effects of vehicle and $5 \mathrm{mg} / \mathrm{kg}$ citalopram on 5-HTP and DOPA accumulation in different strains were analyzed by two-way ANOVA, with strain and treatment as main factors. Likewise, brain and plasma levels of citalopram in different strains of mice given 2.5 and $5 \mathrm{mg} / \mathrm{kg}$ of the drug were compared by two-way ANOVA, with strain and treatment as main factors. The effect of citalopram on immobility time in each strain was compared with that vehicle by one-way ANOVA. Post hoc comparisons between means were made by Tukey-Kramer's test.

\section{Results}

Figure 1 shows the $\mathrm{C} 1473 \mathrm{G}$ polymorphism of TPH-2 and its different allelic distribution in C57BL/6J, 129/Sv, DBA/2J, and BALB/C mice. In agreement with previous results, C57BL/6J and 129/Sv mice are homozygous for the allele $\mathrm{C}$ and $\mathrm{DBA} / 2 \mathrm{~J}$ and $\mathrm{BALB} / \mathrm{c}$ mice for the allele G. PCR amplification of the $\beta$-actin gene confirmed that DNA was not damaged (data not shown). 
$\mathrm{L}(\mathrm{bp})$

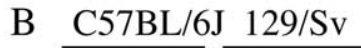

$\underline{\mathrm{DBA} / 2 \mathrm{~J}} \underline{\mathrm{BALB} / \mathrm{C}} \quad \mathrm{B} \quad \mathrm{L}(\mathrm{bp})$
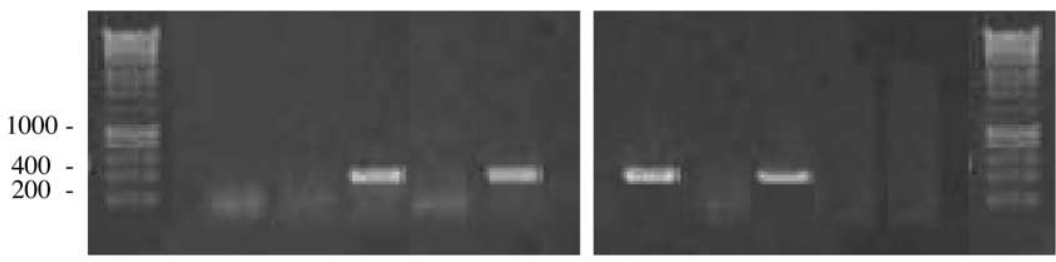

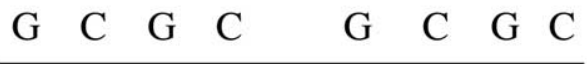

allele-specific primer

Figure 1. Genotypic analysis of C57BL/6J, 129/Sv, DBA/2J, and BALB/C mice strains to assess (1473G polymorphism in the mTph2 gene shows that $C 57 \mathrm{BL} / 6$ J and $129 /$ Sv strains have the C allele, and DBA/2J and BALB/C strains have the $G$ allele. L, DNA ladder; B, PCR control sample.

Table 1. Immobility time (pool of two experiments) of mice treated with vehicle

\begin{tabular}{ll}
\hline Strain & Immobility time $(s)$ \\
\hline C57BL/6J & $170.9 \pm 4.7(n=26)$ \\
$129 / \mathrm{Sv}$ & $204.6 \pm 4.4^{*}(n=20)$ \\
$\mathrm{DBA} / 2 \mathrm{~J}$ & $159.8 \pm 6.8(n=22)$ \\
$\mathrm{BALB} / \mathrm{C}$ & $171.8 \pm 5.1(n=20)$ \\
\hline
\end{tabular}

Data are means \pm SEM; the number of mice in each group is indicated in parentheses. ${ }^{*} p<0.05$ versus $(57 \mathrm{BL} / 6 \mathrm{~J}$ $\mathrm{DBA} / 2 \mathrm{~J}$, and $\mathrm{BALB} / \mathrm{C}$

\section{Effect of citalopram on immobility time and open-field activity \\ Immobility time}

Because no significant differences were found between experiments in basal immobility time regardless of the number of vehicle injections $\left(\mathrm{C} 57 \mathrm{BL} / 6 \mathrm{~J}, t_{(24)}=1.1, p=0.3 ; 129 / \mathrm{Sv}, t_{(18)}=0.7\right.$, $\left.p=0.5 ; \mathrm{DBA} / 2 \mathrm{~J}, t_{(20)}=0.3, p=0.8 ; \mathrm{BALB} / \mathrm{c}, t_{(18)}=1.2, p=0.3\right)$, data from each strain were pooled. As reported in Table 1 , there was a significant difference in the basal immobility time between strains $\left(F_{(3,84)}=12.3 ; p<0.0001\right)$. Immobility time in $129 / \mathrm{Sv}$ mice was significantly longer than the other strains $(p<0.05$, Tukey-Kramer's test). No significant differences were found in basal immobility between C57BL/6J, DBA/2J, and BALB/c mice.

Marked differences were found in the responses of the four strains to citalopram in the FST (Fig. 2). Overall, two-way ANOVA indicates a significant effect of strain $\left(F_{(2,106)}=14.9\right.$; $p<0.0001)$, treatment $\left(F_{(3,106)}=43.6 ; p<0.0001\right)$, and strain $\times$ treatment interaction $\left(F_{(6,106)}=12.8 ; p<0.0001\right)$. Citalopram dose dependently reduced immobility time in C57BL/6J mice $\left(F_{(3,35)}=18.2 ; p<0.01\right)$. The effect was significant at 2.5 and 5 $\mathrm{mg} / \mathrm{kg}$, whereas $1.25 \mathrm{mg} / \mathrm{kg}$ had no effect. Doses of $2.5,5$, and 10 $\mathrm{mg} / \mathrm{kg}$ significantly reduced immobility in $129 / \mathrm{Sv}$ mice $\left(F_{(3,36)}=\right.$ $6.4 ; p<0.01)$, but the effect was less marked and no dose dependency was observed. Immobility time in DBA/2J $\left(F_{(5,49)}=0.3\right.$; $p>0.05)$ and $\mathrm{BALB} / \mathrm{c}\left(F_{(3,36)}=1.2 ; p>0.05\right)$ mice was not affected by any dose of citalopram.

To evaluate the influence of cylinder size in the response to citalopram, we assessed the effect of the drug on immobility time using a $20-\mathrm{cm}$-wide cylinder. Basal immobility time in DBA/2J mice receiving vehicle was markedly reduced ( $p<0.001$, Student's $t$ test $)$ in the large cylinder $(60.7 \pm 11.3 \mathrm{~s} ; n=7)$ compared with the smaller cylinder $(158.2 \pm 10.4 \mathrm{~s} ; n=12)$, whereas no significant changes were observed in C57BL/6J mice (in the narrow and large cylinders, respectively, $165.0 \pm 8.6 \mathrm{~s}, n=11$; and $156.0 \pm 9.9 \mathrm{~s}, n=9$ ). With the $20 \mathrm{~cm}$ cylinder, $5 \mathrm{mg} / \mathrm{kg}$ citalopram significantly reduced immobility time in $\mathrm{C} 57 \mathrm{BL} / 6 \mathrm{~J}$ mice
$(98 \pm 15.7 \mathrm{~s} ; n=9 ; p=0.006$ vs vehicle, Student's $t$ test) but had no effect in $\mathrm{DBA} / 2 \mathrm{~J}$ mice $(61.4 \pm 15.9, n=6 ; 67.8 \pm$ $7.8, n=6$; and $58.6 \pm 7.2, n=7 \mathrm{~s}$, in mice given 5,10 , and $20 \mathrm{mg} / \mathrm{kg}$ citalopram, respectively; $F_{(3,22)}=0.1 ; p=0.9$; one-way ANOVA).

\section{Open-field activity}

As reported in Table 2, significant differences in spontaneous locomotion were found between strains. 129/Sv mice were less active than C57BL/6J mice $\left(t_{(14)}=\right.$ $13.3 ; p<0.001$, Student's $t$ test $)$, whereas $\mathrm{BALB} / \mathrm{c}$ were less active than DBA/2J mice $\left(t_{(15)}=7.1 ; p<0.001\right.$, Student's $t$ test $)$. In general, DBA/2J mice were the most active, followed by C57BL/6J, BALB/c, and $129 /$ Sv. However, the comparison of the four strains is only tentative because C57BL/6J and 129/Sv mice received only one injection of vehicle, whereas DBA/2J and BALB/c mice were given two. C57BL/6J and 129/Sv mice showed no change in the openfield activity after doses of citalopram that reduced immobility time in the FST, although a tendency to a reduction was observed in $129 / \mathrm{Sv}$ mice $\left(\mathrm{C} 57 \mathrm{BL} / 6 \mathrm{~J}, F_{(3,28)}=1.3, p=0.3 ; 129 / \mathrm{Sv}, F_{(3,28)}=\right.$ $0.9, p=0.5)$.

Table 2 shows that TRP and citalopram singly or coadministered did not affect the locomotor activity of DBA/2J mice $\left(F_{\mathrm{TRP}}(1,28)=3.6, p>0.05 ; F_{\text {citalopram }(1,28)}=0.2, p>0.05\right.$; $\left.F_{\text {TRP } \times \text { citalopram }(1,28)}=0.72, p>0.05\right)$. In BALB/c mice, however, citalopram significantly enhanced open-field activity $\left(F_{\text {citalopram }(1,29)}=16.5 ; p=0.0003\right)$. This effect was not modified by pretreatment with TRP $\left(F_{\mathrm{TRP}} \times\right.$ citalopram $\left.(1,29)=2.1 ; p=0.16\right)$

TRP had no effect on locomotor activity in $\mathrm{BALB} / \mathrm{c}$ mice $\left(F_{\mathrm{TRP}(1,29)}=0.9 ; p=0.3\right)$.

\section{Brain levels of citalopram}

Mean citalopram brain concentrations rose with the dose in all strains. After $5 \mathrm{mg} / \mathrm{kg}$ citalopram, at the end of the behavioral test, levels were similar in all strains except 129/Sv mice, which had significantly higher levels than BALB/c mice (Table 3 ). Brain drug levels in $129 / \mathrm{Sv}$ mice given $2.5 \mathrm{mg} / \mathrm{kg}$ citalopram were significantly higher than in C57BL/6J and DBA/2J mice, but, in the latter strain, they were significantly lower than in BALB/c mice. Overall, ANOVA indicated a significant effect of strain $\left(F_{(3,67)}=\right.$ $7.4 ; p=0.0002)$ and treatment $\left(F_{(1,67)}=182.6 ; p<0.0001\right)$ but not strain $\times$ treatment interaction $\left(F_{(3,67)}=2.7 ; p=0.06\right)$.

Citalopram concentrations in plasma were lower than in brain, with significant differences between strains. Plasma levels of citalopram in 129/Sv mice were higher than in BALB/c and C57BL/6J mice but similar to those in DBA/2J mice (data not shown). Mean plasma concentrations of $N$-demethylcitalopram increased with the citalopram dose in all strains. However, at 1.25 and $2.5 \mathrm{mg} / \mathrm{kg}$, it was below the LOQ (data not shown). The metabolite was never detectable in the brain $(<0.08 \mu \mathrm{g} / \mathrm{g})$.

\section{Accumulation of 5-HTP and DOPA and concentrations of 5-HT}

5-HT synthesis, measured by basal 5-HTP accumulation, in the whole brain of $\mathrm{DBA} / 2 \mathrm{~J}$ and $\mathrm{BALB} / \mathrm{c}$ mice given vehicle was significantly lower than in other strains $\left(F_{(3,26)}=18.3 ; p<0.0001\right)$. Brain 5-HTP content in DBA/2J and BALB/c mice was $\sim 30 \%$ lower than in C57BL/6J and $\sim 40 \%$ lower than in $129 / \mathrm{Sv}$ mice 


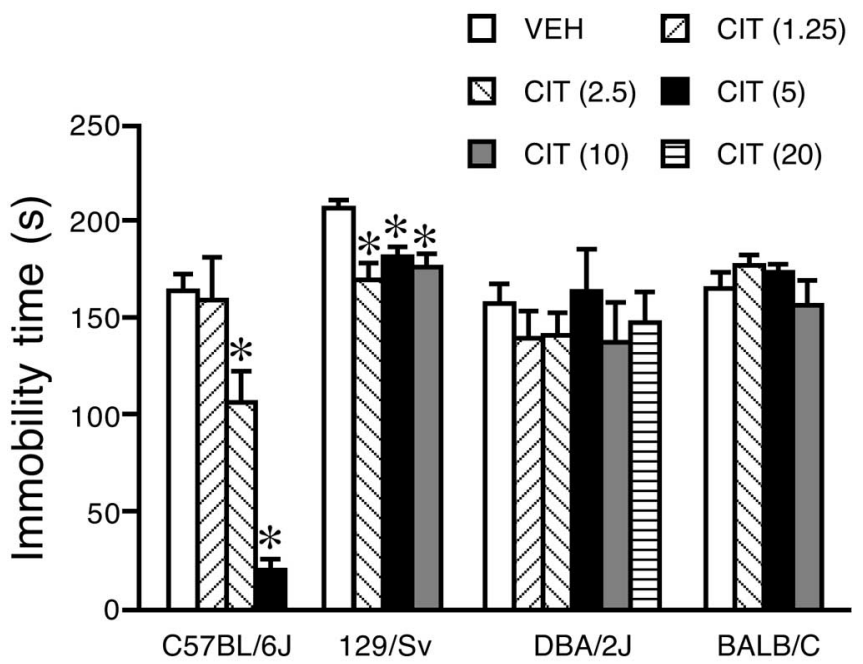

Figure 2. Strain differences in the effect of citalopram in the forced swimming test. Mice were given citalopram (CIT; doses expressed as milligrams per kilogram, in parentheses) $30 \mathrm{~min}$ before testing. Data are means \pm SEM of $7-11$ mice per group. ${ }^{*} p<0.05$ versus respective vehicle (VEH), Tukey-Kramer's test.

Table 2. Open-field activity in C57BL/6J, 129/Sv, DBA/2J, and BALB/c mice given different doses of citalopram alone or in combination with TRP

\begin{tabular}{lll}
\hline Dose of citalopram $(\mathrm{mg} / \mathrm{kg})$ & C57BL/6J & $129 / \mathrm{Sv}$ \\
\hline Veh & $150.9 \pm 6.3(n=8)$ & $27.1 \pm 6.8(n=8)$ \\
1.25 & $143.8 \pm 8.5(n=8)$ & $\mathrm{ND}$ \\
2.5 & $153.6 \pm 10.4(n=8)$ & $13.5 \pm 6.2(n=8)$ \\
5.0 & $167.1 \pm 7.9(n=8)$ & $16.1 \pm 10.6(n=8)$ \\
10.0 & $\mathrm{ND}$ & $11.3 \pm 4.8(n=8)$ \\
\hline Treatment & $\mathrm{DBA} / 2 \mathrm{~J}$ & $\mathrm{BALB} / \mathrm{C}$ \\
\hline Veh plus Veh & $208.3 \pm 12.3(n=8)$ & $94.0 \pm 10.3(n=9)$ \\
Veh plus Citalopram & $232.6 \pm 23.2(n=8)$ & $160.3 \pm 13.9^{*}(n=8)$ \\
TRP plus Veh & $189.3 \pm 14.6(n=8)$ & $99.9 \pm 4.7(n=8)$ \\
TRP plus Citalopram & $182.9 \pm 20.1(n=8)$ & $131.5 \pm 16.4(n=8)$ \\
\hline
\end{tabular}

Top, Effects of different doses of citalopram or vehicle (Veh) on open-field activity in C57BL/6J and 129/Sv mice. Bottom, Effects of TRP $(300 \mathrm{mg} / \mathrm{kg}$ ), citalopram $(5 \mathrm{mg} / \mathrm{kg})$, and vehicle alone or in combination on open-field activity in DBA/2J and BALB/c mice. Data are mean \pm SEM. The number of mice is indicated in parentheses. ${ }^{*} p<0.05$ versus Veh plus Veh (Tukey-Kramer's test). ND, Not determined.

(Fig. 3). Basal levels of 5-HTP in C57BL/6J and 129/Sv mice were not significantly different. Likewise, no differences were observed between $\mathrm{DBA} / 2 \mathrm{~J}$ and $\mathrm{BALB} / \mathrm{c}$ mice.

The concentrations of 5-HT in the brain of untreated DBA/2J and $\mathrm{BALB} / \mathrm{c}$ mice were, respectively, $426 \pm 9 \mathrm{ng} / \mathrm{g}(n=7)$ and $393 \pm 13 \mathrm{ng} / \mathrm{g}(n=6)$. These values were significantly lower (both $p<0.05$, Tukey-Kramer's test) than in C57BL/6J (477 \pm 11 $\mathrm{ng} / \mathrm{g} ; n=7)$ and $129 / \mathrm{Sv}(493 \pm 19 \mathrm{ng} / \mathrm{g} ; n=6)$ mice $\left(F_{(3,22)}=\right.$ $12.1 ; p<0.0001)$.

Citalopram at $5 \mathrm{mg} / \mathrm{kg}$ inhibited brain 5-HT synthesis by $37 \%$ in $\mathrm{C} 57 \mathrm{BL} / 6 \mathrm{~J}$ mice and by $42 \%$ in $129 / \mathrm{Sv}$ mice. Citalopram at 5 $\mathrm{mg} / \mathrm{kg}$ had significantly less overall effect in DBA/2J and BALB/c mice than C57BL/6J and $129 / \mathrm{Sv}$ mice $\left(F_{\text {strain }(3,49)}=22.9, p<\right.$ $0.0001 ; F_{\text {treatment }(1,49)}=74, p<0.0001 ; F_{\text {strain } \times \text { treatment }(3,49)}=$ $5.5, p<0.003)$. The effect of $5 \mathrm{mg} / \mathrm{kg}$ citalopram was probably maximal because there was no additional reduction of 5-HTP accumulation at the dose of $20 \mathrm{mg} / \mathrm{kg}$ in C57BL/6J (-46\%) and DBA/2J (-23\%) mice. Citalopram at $20 \mathrm{mg} / \mathrm{kg}$ reduced 5-HTP accumulation in $\mathrm{C} 57 \mathrm{BL} / 6 \mathrm{~J}$ mice more than in DBA/2J mice $\left(F_{\text {strain }(1,21)}=14.1, p=0.0011 ; F_{\text {treatment }(1,21)}=63, p<0.0001\right.$; $\left.F_{\text {strain } \times \text { treatment }(1,29)}=15.2, p=0.0008\right)$ (Fig. 3). Basal striatal accumulation of 5-HTP in DBA/2J mice was $42 \%$ lower than in
C57BL/6J mice (data not shown). Citalopram reduced 5-HTP in the striatum of C57BL/6J mice by $\sim 30 \%$ at both 5 and $20 \mathrm{mg} / \mathrm{kg}$ but had no significant effect in DBA/2J mice (data not shown).

No effects of strain or citalopram were found on the accumulation of whole brain DOPA (Fig. 3).

\section{Effects of TRP and PCPA on 5-HTP accumulation and citalopram-induced immobility}

In DBA/2J (Fig. 4b) and BALB/c (Fig. 4d) mice, $300 \mathrm{mg} / \mathrm{kg}$ TRP raised brain 5-HTP accumulation more than twofold but had no effect on DOPA accumulation. At 30 and $100 \mathrm{mg} / \mathrm{kg}$, TRP had no effects on 5-HTP and DOPA accumulation.

As shown in Figure 4, $a$ and $c$, a single dose of citalopram, which had no effect on immobility time in DBA/2J or BALB/c mice, significantly reduced immobility time in mice pretreated with $300 \mathrm{mg} / \mathrm{kg}$ TRP $\left(\mathrm{DBA} / 2 \mathrm{~J}, F_{(1,36)}=11.7, p<0.01 ; \mathrm{BALB} / \mathrm{c}\right.$, $\left.F_{(1,36)}=12.3, p<0.01\right)$, and TRP by itself did not change immobility time in both strains.

Doses of $100 \mathrm{mg} \cdot \mathrm{kg}^{-1} \cdot \mathrm{d}^{-1}$ PCPA for $3 \mathrm{~d}$ reduced the accumulation of brain 5-HTP in C57BL/6J (Fig. 5b) and 129/Sv (Fig. $5 d$ ) mice by, respectively, 70 and $50 \%$ and prevented the reduction of immobility time by $5 \mathrm{mg} / \mathrm{kg}$ citalopram (C57BL/6), $\left.F_{(1,56)}=6.7, p<0.05 ; 129 / \mathrm{Sv}, F_{(1,36)}=8.5, p<0.01\right)$ (Fig. $\left.5 a, c\right)$.

Brain levels of citalopram were not significantly affected by pretreatment with PCPA (C57BL/6J mice: vehicle plus citalopram, $1.5 \pm 0.3 \mathrm{ng} / \mathrm{g}$; PCPA plus citalopram, $1.6 \pm 0.3 \mathrm{ng} / \mathrm{g}$; 129/Sv mice: vehicle plus citalopram, $1.4 \pm 0.2 \mathrm{ng} / \mathrm{g}$; PCPA plus citalopram, $1.3 \pm 0.1 \mathrm{ng} / \mathrm{g})$. Likewise, TRP had no effect on brain levels of citalopram (DBA/2J mice: vehicle plus citalopram, $1.0 \pm$ $0.1 \mathrm{ng} / \mathrm{g}$; TRP plus citalopram, $1.0 \pm 0.23 \mathrm{ng} / \mathrm{g} ; \mathrm{BALB} / \mathrm{c}$ mice: vehicle plus citalopram, $1.2 \pm 0.2 \mathrm{ng} / \mathrm{g}$; TRP plus citalopram, $1.2 \pm 0.1 \mathrm{ng} / \mathrm{g})$.

\section{Discussion}

Citalopram reduced immobility time in the FST in C57BL/6J and $129 / \mathrm{Sv}$ but not in DBA/2J and BALB/c inbred mice even at four times higher doses. This strongly suggests that genetic differences play a role in this response. The different effects are not attributable to pharmacokinetic factors because brain citalopram levels were essentially similar in the four strains after the behavioral test. Slightly lower levels of citalopram in the brain of DBA/2J mice given $2.5 \mathrm{mg} / \mathrm{kg}$ citalopram or in BALB/c mice given $5 \mathrm{mg} / \mathrm{kg}$ are mostly corrected by increasing the dose and are unlikely to account for the lack of response of these strains in the FST. The main metabolite $N$-demethylcitalopram was undetectable in the brain of all strains, suggesting that it does not play a significant role in the effects of the parent drug.

Doses of citalopram reducing immobility time in C57BL/6J and $129 / \mathrm{Sv}$ mice had no effect on locomotor activity. Thus, the data on locomotion do not support the involvement of motor performance in the FST response to citalopram. Likewise, citalopram and paroxetine reduced the immobility time in NIH-Swiss mice at doses with no effect on locomotion (David et al., 2003). Citalopram had less anti-immobility effect in $129 / \mathrm{Sv}$ mice than in C57BL/6J mice, and no dose dependency was observed. This may be partly explained by the fact that this strain performs poorly in several tests involving locomotor activity and/or exploration, such as open field (present study) or Y maze and Barnes maze (Wahlsten et al., 2003). However, differences in locomotor activity can hardly explain the different effects of citalopram in the FST in the other strains.

The mouse strains used in the present study differ in several neurochemical parameters potentially involved in the antide- 
Table 3. Brain levels of citalopram in C57BL/6J, 129/Sv, DBA/2J, and BALB/c mice given different doses of the drug intraperitoneally

\begin{tabular}{lllll}
\hline Dose of citalopram $(\mathrm{mg} / \mathrm{kg})$ & C57BL/6J & 129/Sv & DBA/2J & BALB/C \\
\hline 1.25 & $0.15 \pm 0.03$ & ND & $0.12 \pm 0.04$ & ND \\
2.5 & $0.34 \pm 0.09^{*}$ & $0.48 \pm 0.16$ & $0.25 \pm 0.08^{*}, \#$ & $0.40 \pm 0.06$ \\
5.0 & $0.99 \pm 0.24$ & $1.33 \pm 0.39$ & $1.00 \pm 0.10$ & $0.87 \pm 0.32^{*}$ \\
10.0 & ND & $3.32 \pm 0.62$ & $2.95 \pm 0.26$ & $3.26 \pm 0.87$ \\
20.0 & ND & ND & $5.75 \pm 0.46$ & ND \\
\hline
\end{tabular}

At the end of the behavioral test, $37-40$ min after citalopram injection, C57BL/6J $(n=8-10), 129 / \mathrm{Sv}(n=9-10), \mathrm{DBA} / 2 \mathrm{~J}(n=8-10)$, and BALB/C $(n=$ $5-10)$ mice (the same as in Fig. 2) were killed. Brain levels of citalopram were determined as described in Materials and Methods. Data are means $\pm S D .{ }^{*} p<$ 0.05 versus $129 / \mathrm{Sv} ; \# p 0.05$ versus BALB/c (Tukey-Kramer's test). ND, Not determined.
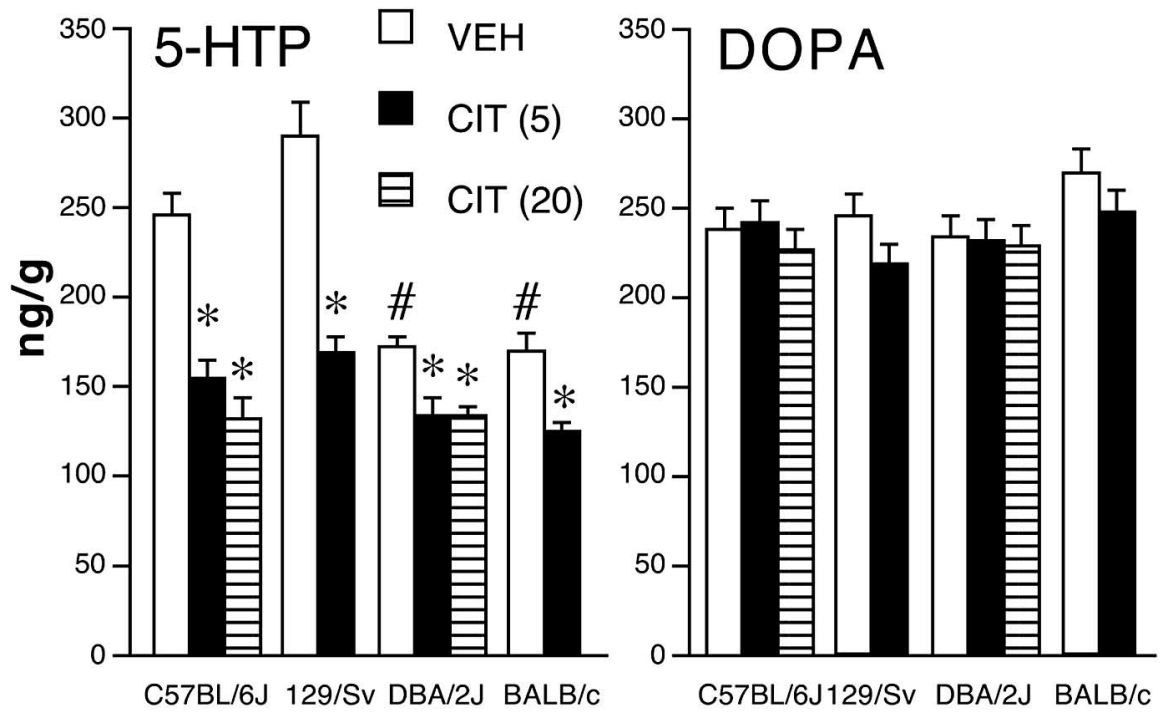

Figure 3. Effect of citalopram on whole-brain 5-HT and catecholamine synthesis as assessed by 5-HTP and DOPA accumulation after decarboxylase inhibition. Mice were given citalopram (CIT; doses expressed as milligrams per kilogram, shown in parentheses) 30 min before $m$-hydroxybenzylhydrazine and killed 30 min later. The citalopram-induced decrease of 5 -HTP in DBA/2J (5-6 per group) and BALB/C (8 per group) mice was significantly less than in C57BL/6J (6-7 per group) and 129/Sv (8-9 per group) mice (for $F$ values, see Results). Data are means \pm SEM. ${ }^{*} p<0.05$ versus vehicle (VEH); ${ }^{\#} p<0.05$ versus (57BL/6J and $129 / \mathrm{Sv}$ vehicle-treated mice (Tukey-Kramer's test).

pressant response. These include the content of brain noradrenaline (NA) (Kempf et al., 1974), the number of noradrenaline uptake sites in the locus ceruleus (Hwang et al., 1999), and the density of hippocampal glutamate, GABA, and 5-HT receptors (Zilles et al., 2000). Although we cannot exclude an effect of these differences, the results suggest that the failure of citalopram to reduce immobility in $\mathrm{DBA} / 2 \mathrm{~J}$ and $\mathrm{BALB} / \mathrm{c}$ mice is mainly attributable to the genotype-dependent impairment of 5-HT synthesis.

This is supported by several findings. First, unresponsive strains (DBA/2J and BALB/c) are homozygous for the $1473 \mathrm{G}$ allele of TPH-2, whereas responsive strains (C57BL/6J and 129/ $\mathrm{Sv}$ ) are homozygous for the $1473 \mathrm{C}$ allele. This polymorphism, first reported by Zhang et al. (2004), was confirmed by the present study.

Second, in keeping with previous findings (Zhang et al., 2004), 5-HTP accumulation in the whole brain and striatum and 5-HT levels in the brain of DBA/2J and BALB/c mice were significantly lower than in the C57BL/6J and 129/Sv strains. Furthermore, citalopram inhibited brain 5-HT synthesis in C57BL/6J and $129 / \mathrm{Sv}$ mice but had significantly less effect in DBA/2J and $\mathrm{BALB} / \mathrm{c}$ mice and no real effect in the striatum of DBA/2J mice. The fact that strain and citalopram had no effect on the accumulation of DOPA, the precursor of catecholamines, indicates the specificity of strain differences in 5-HTP accumulation and con- firms that catecholamines are not involved in the antidepressant-like effect of citalopram (Cryan et al., 2004).

Third, enhancement of 5-HT synthesis by the 5 -HT precursor TRP reinstated the anti-immobility effect of citalopram in $\mathrm{DBA} / 2 \mathrm{~J}$ and $\mathrm{BALB} / \mathrm{c}$ mice, whereas the inhibition of 5-HT synthesis with PCPA prevented the antidepressant-like effect of citalopram in C57BL/6J and 129/Sv mice. This indicates that brain 5-HT synthesis plays a major role in the antidepressantlike effect of citalopram.

The effect of citalopram on immobility time in mice given TRP or PCPA cannot be accounted for by differences in drug disposition because brain concentrations immediately after the FST were not modified. Also, motor performance was not altered in $\mathrm{DBA} / 2 \mathrm{~J}$ mice given citalopram, TRP, or the combination. Although citalopram increased locomotor activity by itself, immobility was reduced in $\mathrm{BALB} / \mathrm{c}$ mice given TRP plus citalopram without any change in locomotion.

Interestingly, PCPA and TRP did not change basal immobility time. Thus, stimulation, and particularly reduction of 5-HT synthesis, may be not sufficient to affect behavior in the FST. Previous studies reported no effects of PCPA or the serotonergic neurotoxin 5,7-dihydroxytryptamine on immobility time in mice and rats (Cervo and Samanin, 1991; Borsini, 1995; Redrobe et al., 1998; Page et al., 1999). Likewise, doses of TRP close to that we used had no effect on immobility time in NIH-Swiss mice, whereas at 50$125 \mathrm{mg} / \mathrm{kg}$ TRP reduced immobility (Hilakivi-Clarke et al., 1990; Wong and Ong, 2001).

The lack of response to citalopram in DBA/2J mice does not seem to be related to adaptive changes or abnormal 5-HT uptake because synaptosomal 5-HT uptake was similar in various brain regions of $\mathrm{C} 57 \mathrm{BL} / 6 \mathrm{~J}$ and DBA/2J mice (Jazrawi and Horton, 1989). The failure of citalopram to reduce immobility in DBA/2J mice is consistent with another report that citalopram and paroxetine did not affect immobility time in this strain (David et al., 2003). However, Lucki et al. (2001) showed that fluoxetine reduced immobility time in DBA/2J and BALB/c mice, had no effect in C57BL/6J, and increased immobility in 129/SvemJ mice. Although this apparently argues against a role for allelic differences in TPH-2 in the effect of SSRIs, the genotype-environment interaction may cause differences in behavioral phenotype across laboratories (Crabbe et al., 1999; Wahlsten et al., 2003; Kafkafi et al., 2005). Differences in the SSRIs, substrain, and procedures used may also contribute.

In particular, differences in the effects of SSRIs in the FST may reflect differences in selectivity among SSRIs. Fluoxetine, at doses increasing extracellular 5-HT, also raised extracellular dopamine (DA) and NA in the rat medial prefrontal cortex (Jordan et al., 1994; Tanda et al., 1994; Pozzi et al., 1999), and its effect on DA was not modified by neurotoxic lesion of 5 -HT neurons with 5,7-dihydroxytryptamine, which completely prevented the rise of 

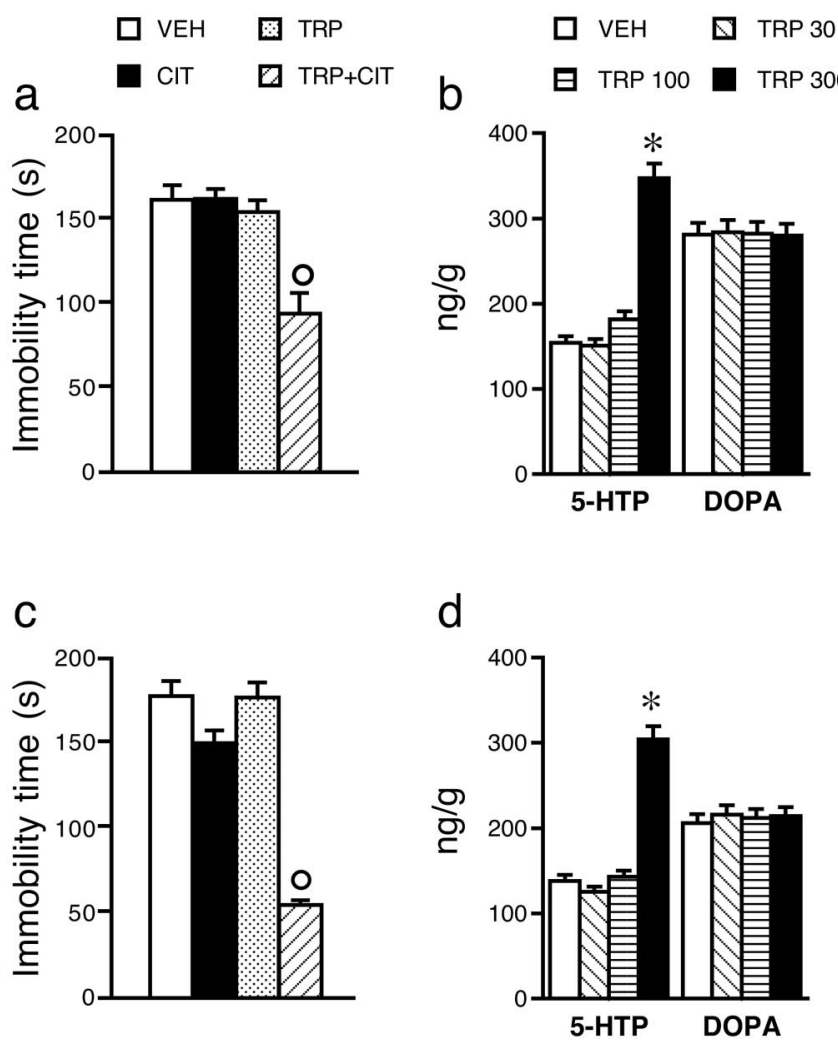

Figure 4. Effect of TRP and citalopram (CIT) coadministered on immobility time and accumulation of brain 5-HTP and DOPA in DBA/2J $(\boldsymbol{a}, \boldsymbol{b})$ and BALB/C $(\boldsymbol{c}, \boldsymbol{d})$ mice. Mice received vehicle (VEH) or $300 \mathrm{mg} / \mathrm{kg}$ intraperitoneal tryptophan $30 \mathrm{~min}$ before saline or $5 \mathrm{mg} / \mathrm{kg}$ citalopram (CIT) and were tested $30 \mathrm{~min}$ after citalopram ( $\boldsymbol{a}, \boldsymbol{c} ; n=10$ per group). The effect of $30-300 \mathrm{mg} / \mathrm{kg}$ tryptophan on 5-HTP and DOPA accumulation in DBA/2J $(\boldsymbol{b})$ and BALB/C $(\boldsymbol{d})$ mice was assessed in separate groups of six mice. Data are means \pm SEM. ${ }^{*} p<0.05$ versus respective vehicle; ${ }^{\circ} \mathrm{p}<0.05$ versus citalopram (Tukey-Kramer's test).

extracellular 5-HT (Pozzi et al., 1999). Although 5-HT depletion prevented the anti-immobility effect of fluoxetine in the FST in rats and mice (Page et al., 1999; Rodrigues et al., 2002; Gavioli et al., 2004), it had much less effect (like that of paroxetine and sertraline) in dopamine $\beta$-hydroxylase (Dbh) knock-out mice (Cryan et al., 2004), whereas the anti-immobility effect of sertraline in rats was not affected by 5 -HT depletion (Cervo et al., 1991). Unfortunately, Lucki et al. (2001) did not assess whether the anti-immobility effect of fluoxetine in DBA/2J mice depends on endogenous 5-HT.

Citalopram is reported to inhibit NA reuptake in NA transporter knock-out mice (Vizi et al., 2004), but it has no effect on extracellular NA in animals with a functional NA transporter, unless very high doses are used (Pozzi et al., 1999). Thus, the antidepressant-like effect of citalopram was completely prevented by the 5-HT synthesis inhibitor PCPA (present study) but was unchanged in mice with deletion of the NA transporter (Vizi et al., 2004) or the Dbh genes (Cryan et al., 2004).

It has been suggested that, when the diameter of the cylinder used to assess immobility is $20 \mathrm{~cm}$ or bigger, there may be fewer false-positive errors in the mice FST (Sunal et al., 1994; PetitDemouliere et al., 2005). In line with previous findings (David et al., 2003), we observed no differences in basal immobility time between $\mathrm{C} 57 \mathrm{BL} / 6 \mathrm{~J}, \mathrm{DBA} / 2 \mathrm{~J}$, and $\mathrm{BALB} / \mathrm{c}$ mice using the $10 \mathrm{~cm}$ cylinder, whereas $129 / \mathrm{Sv}$ mice were more immobile than other strains. However, using the $20 \mathrm{~cm}$ cylinder, basal immobility time was strongly reduced in DBA/2J but not in C57BL/6J mice. Con-
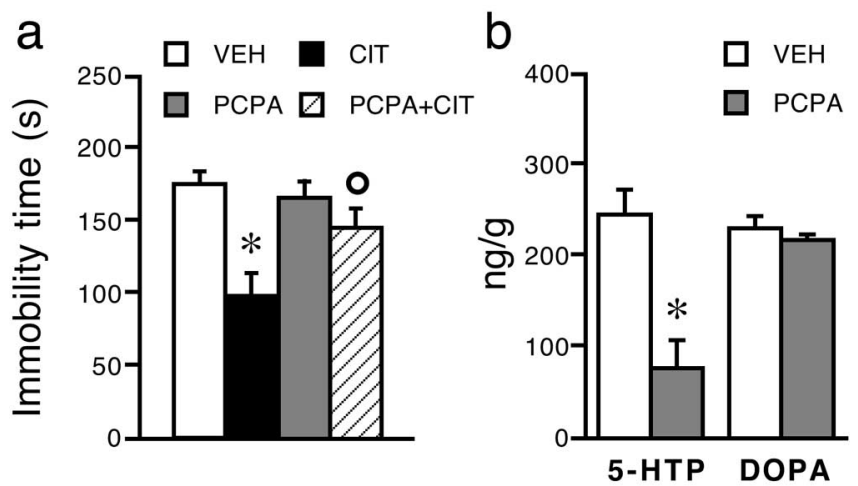

C

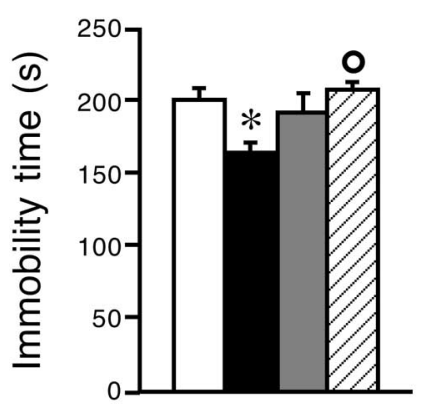

d

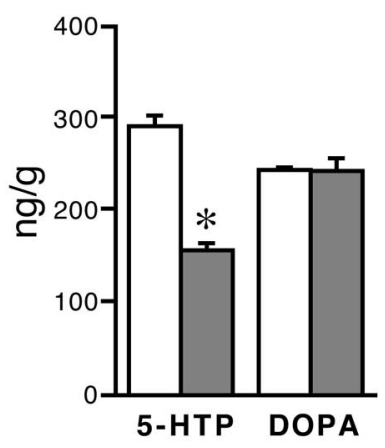

Figure 5. Effect of PCPA on citalopram-induced reduction of immobility time and accumulation of brain 5-HTP and DOPA in C57BL/6J ( $(\boldsymbol{a}, \boldsymbol{b})$ and 129/Sv ( $\boldsymbol{c}, \boldsymbol{d})$ mice. C57BL/6) ( $n=15$ per group) and $129 / \mathrm{Sv}$ ( $n=10$ per group) mice were given vehicle (VEH) or PCPA (100 mg/kg orally for 3 consecutive days). Twenty-four hours after the last dose, they were given saline or $5 \mathrm{mg} / \mathrm{kg}$ citalopram (CIT) and tested 30 min later. Separate groups of C57BL/6J (b) and 129/Sv (d) mice were given PCPA or vehicle ( $n=5-6$ per group), and brain 5 -HTP and DOPA accumulation was measured $24 \mathrm{~h}$ after the last dose. Data are means $\pm S E M .{ }^{*} p<0.05$ versus respective vehicle; ${ }^{\circ} p<0.05$ versus citalopram (Tukey-Kramer's test).

sistently, DBA/2J mice were less immobile than C57BL/6J mice in a $20 \mathrm{~cm}$ cylinder (Lucki et al., 2001). Despite the marked changes in basal immobility, the different responses of C57BL/6J and DBA/2J mice to citalopram were not affected by the size of the cylinder. Thus, the effect of established antidepressant drugs in the FST did not depend on the cylinder diameter (Sunal et al., 1994), which is therefore unlikely to account for the differences between the present findings and those of Lucki et al. (2001). It remains to be clarified whether other procedural differences contributed.

Active behavior in the FST can be distinguished into climbing and swimming (Cryan et al., 2002a). Mice with shorter immobility time in response to citalopram alone (C57BL/6J and 129/Sv) or with TRP (DBA/2J and BALB/c) increased their active swimming, with no significant effect on climbing (A. Canetta and L. Cervo, unpublished observations). These different behavioral profiles are consistent with previous reports that antidepressants blocking 5-HT reuptake preferentially increase swimming in rats (Detke et al., 1995; Reneric and Lucki, 1998) and mice (Alcaro et al., 2002).

SSRI-induced inhibition of 5-HT synthesis depends on the ability of the drugs to enhance endogenous 5-HT tone on 5-HT receptors, which in turn inhibits 5-HT synthesis (Stenfors et al., 2001). Because the inhibition of 5-HT synthesis by citalopram is reversed by $5-\mathrm{HT}_{1 \mathrm{~A}}$ and $5-\mathrm{HT}_{1 \mathrm{~B} / 1 \mathrm{D}}$ receptor antagonists (Barton and Hutson, 1999), it has been suggested that autoreceptor activation plays a major role. However, other studies failed to con- 
firm this and suggested that some other 5-HT receptor subtype contributes (Moret and Briley, 1997; Stenfors et al., 2001). Interestingly, TRP and the activation of TPH by $\mathrm{Ca} /$ calmodulin kinase $\mathrm{II}$ and protein kinase A enhanced $5-\mathrm{HT}_{1 \mathrm{~A}}$ receptor-mediated inhibition of dorsal raphe 5-HT neurons (Liu et al., 2005). Thus, autoreceptor-mediated inhibition of brain 5-HT synthesis is quite likely impaired in DBA/2J and BALB/c mice.

The present results suggest that strategies to stimulate 5-HT synthesis might enhance the antidepressant effect of SSRIs in depressed patients carrying the A/A and G/A alleles of TPH-2, who, according to the only available study, may amount to $10 \%$ (Zhang et al., 2005). Clinical studies have shown that the therapeutic effect of SSRIs in drug-remitted depressed patients was reversed by the 5-HT synthesis inhibitor PCPA and by TRP depletion (Shopsin et al., 1976; Delgado et al., 1990). However, the combination of TRP with fluoxetine, zimelidine, clomipramine, and amitryptyline has only occasionally achieved any potentiation or acceleration of the clinical effect, and we do not know how TRP augmentation affect patients not responding to SSRIs (Young, 1991; Young and Leyton, 2002). Thus, it would be important to establish whether this strategy improves the therapeutic outcome in this subgroup, particularly patients carrying the $\mathrm{A} / \mathrm{A}$ and G/A alleles of TPH-2.

In conclusion, the results provide functional evidence that the genotype-dependent regulation of 5-HT synthesis is an important factor in the antidepressant-like action of citalopram. Interstrain comparisons are important for a clearer understanding of the mechanisms underlying the response to SSRIs.

\section{References}

Alcaro A, Cabib S, Ventura R, Puglisi-Allegra S (2002) Genotype- and experience-dependent susceptibility to depressive-like responses in the forced-swimming test. Psychopharmacology (Berl) 164:138-143.

Barton CL, Hutson PH (1999) Inhibition of hippocampal 5-HT synthesis by fluoxetine and paroxetine: evidence for the involvement of both 5-HT1A and 5-HT1B/D autoreceptors. Synapse 31:13-19.

Borsini F (1995) Role of the serotonergic system in the forced swimming test. Neurosci Biobehav Rev 19:377-395.

Broadhurst AM, Briley M (1988) Catecholamine and 5-HT synthesis ex vivo as an index of in-vivo neuronal activity and regulation. Trends Pharmacol Sci 9:349-351.

Carlsson A, Lindqvist M (1978) Dependence of 5-HT and catecholamine synthesis on concentrations of precursor amino-acids in rat brain. Naunyn Schmiedebergs Arch Pharmacol 303:157-164.

Carlsson A, Davis JN, Kehr W, Lindqvist M, Atack CV (1972) Simultaneous measurement of tyrosine and tryptophan hydroxylase activities in brain in vivo using an inhibitor of the aromatic amino acid decarboxylase. Naunyn Schmiedebergs Arch Pharmacol 275:153-168.

Cervo L, Samanin R (1991) Effect of chronic treatment with 8-OH-DPAT in the forced swimming test requires the integrity of presynaptic serotonergic mechanisms. Psychopharmacology 103:524-528.

Cervo L, Grignaschi G, Rossi C, Samanin R (1991) Role of central serotonergic neurons in the effect of sertraline in rats in the forced swimming test. Eur J Pharmacol 196:217-222.

Crabbe JC, Wahlsten D, Dudek BC (1999) Genetics of mouse behavior: interactions with laboratory environment. Science 284:1670-1672.

Cryan JF, Markou A, Lucki I (2002) Assessing antidepressant activity in rodents: recent developments and future needs. Trends Pharmacol Sci 23:238-245.

Cryan JF, O'Leary OF, Jin SH, Friedland JC, Ouyang M, Hirsch BR, Page ME, Dalvi A, Thomas SA, Lucki I (2004) Norepinephrine-deficient mice lack responses to antidepressant drugs, including selective serotonin reuptake inhibitors. Proc Natl Acad Sci USA 101:8186-8191.

David DJ, Renard CE, Jolliet P, Hascoet M, Bourin M (2003) Antidepressant-like effects in various mice strains in the forced swimming test. Psychopharmacology (Berl) 166:373-382.

Delgado PL, Charney DS, Price LH, Aghajanian GK, Landis H, Heninger GR (1990) Serotonin function and the mechanism of antidepressant action.
Reversal of antidepressant-induced remission by rapid depletion of plasma tryptophan. Arch Gen Psychiatry 47:411-418.

Detke MJ, Rickels M, Lucki I (1995) Active behaviors in the rat forced swimming test differentially produced by serotonergic and noradrenergic antidepressants. Psychopharmacology (Berl) 121:66-72.

Fava M (2003) Diagnosis and definition of treatment-resistant depression. Biol Psychiatry 53:649-659.

Gavioli EC, Vaughan CW, Marzola G, Guerrini R, Mitchell VA, Zucchini S, De Lima TC, Rae GA, Salvadori S, Regoli D, Calo G (2004) Antidepressant-like effects of the nociceptin/orphanin FQ receptor antagonist UFP-101: new evidence from rats and mice. Naunyn Schmiedebergs Arch Pharmacol 369:547-553.

Grignaschi G, Invernizzi RW, Fanelli E, Fracasso C, Caccia S, Samanin R (1998) Citalopram-induced hypophagia is enhanced by blockade of 5-HT(1A) receptors: role of 5-HT(2C) receptors. Br J Pharmacol 124:1781-1787.

Hilakivi-Clarke LA, Durcan MJ, Lister RG, Linnoila M (1990) Effect of tryptophan on the behavior of nonstressed and stressed mice in Porsolt's swim test. Pharmacol Biochem Behav 37:273-276.

Hwang BH, Kunkler PE, Tarricone BJ, Hingtgen JN, Nurnberger Jr JI (1999) Stress-induced changes of norepinephrine uptake sites in the locus coeruleus of C57BL/6J and DBA/2J mice: a quantitative autoradiographic study using [3H]-tomoxetine. Neurosci Lett 265:151-154.

Hyttel J (1977) Neurochemical characterization of a new potent and selective serotonin uptake inhibitor: Lu 10-171. Psychopharmacology (Berl) 51:225-233.

Jazrawi SP, Horton RW (1989) 5-HT2 receptor binding and 5-HT uptake in mouse brain: developmental changes and the relationship to audiogenic seizure susceptibility in DBA/2J mice. Brain Res Dev Brain Res 45:257-263.

Jordan S, Kramer GL, Zukas PK, Moeller M, Petty F (1994) In vivo biogenic amine efflux in medial prefrontal cortex with imipramine, fluoxetine, and fluvoxamine. Synapse 18:294-297.

Kafkafi N, Benjamini Y, Sakov A, Elmer GI, Golani I (2005) Genotypeenvironment interactions in mouse behavior: a way out of the problem. Proc Natl Acad Sci USA 102:4619-4624.

Kempf E, Greilsamer J, Mack G, Mandel P (1974) Correlation of behavioural differences in three strains of mice with differences in brain amines. Nature 247:483-485.

Koe BK, Weissman A (1966) p-Chlorophenylalanine: a specific depletor of brain serotonin. J Pharmacol Exp Ther 154:499-516.

Lasley SM, Michaelson IA, Greenland RD, McGinnis PM (1984) Simultaneous measurement of tyrosine, tryptophan and related monoamines for determination of neurotransmitter turnover in discrete rat brain regions by liquid chromatography with electrochemical detection. J Chromatogr 305:27-42.

Liu RJ, Lambe EK, Aghajanian GK (2005) Somatodendritic autoreceptor regulation of serotonergic neurons: dependence on L-tryptophan and tryptophan hydroxylase-activating kinases. Eur J Neurosci 21:945-958.

Lucki I, Dalvi A, Mayorga AJ (2001) Sensitivity to the effects of pharmacologically selective antidepressants in different strains of mice. Psychopharmacology (Berl) 155:315-322.

Moret C, Briley M (1997) Ex vivo inhibitory effect of the 5-HT uptake blocker citalopram on 5-HT synthesis. J Neural Transm 104:147-160.

NRC (2003) Guidelines for the care and use of mammals in neuroscience and behavioral research. Washington, DC: National Academy.

Page ME, Detke MJ, Dalvi A, Kirby LG, Lucki I (1999) Serotonergic mediation of the effects of fluoxetine, but not desipramine, in the rat forced swimming test. Psychopharmacology (Berl) 147:162-167.

Petit-Demouliere B, Chenu F, Bourin M (2005) Forced swimming test in mice: a review of antidepressant activity. Psychopharmacology (Berl) 177:245-255.

Pollock BG (2001) Citalopram: a comprehensive review. Expert Opin Pharmacother 2:681-698.

Porsolt RD, Bertin A, Jalfre M (1977) Behavioral despair in mice: a primary screening test for antidepressants. Arch Int Pharmacodyn Ther 229:327-336

Porsolt RD, Anton G, Blavet N, Jalfre M (1978) Behavioural despair in rats: a new model sensitive to antidepressant treatments. Eur J Pharmacol 47:379-391.

Pozzi L, Invernizzi R, Garavaglia C, Samanin R (1999) Fluoxetine increases extracellular dopamine in the prefrontal cortex by a mechanism not de- 
pendent on serotonin: a comparison with citalopram. J Neurochem 73:1051-1057.

Redrobe JP, Bourin M, Colombel MC, Baker GB (1998) Dose-dependent noradrenergic and serotonergic properties of venlafaxine in animal models indicative of antidepressant activity. Psychopharmacology (Berl) 138:1-8.

Renard CE, Dailly E, Nic Dhonnchadha BA, Hascoet M, Bourin M (2004) Is dopamine a limiting factor of the antidepressant-like effect in the mouse forced swimming test? Prog Neuropsychopharmacol Biol Psychiatry 28:1255-1259.

Reneric JP, Lucki I (1998) Antidepressant behavioral effects by dual inhibition of monoamine reuptake in the rat forced swimming test. Psychopharmacology (Berl) 136:190-197.

Rodrigues AL, da Silva GL, Mateussi AS, Fernandes ES, Miguel OG, Yunes RA, Calixto JB, Santos AR (2002) Involvement of monoaminergic system in the antidepressant-like effect of the hydroalcoholic extract of Siphocampylus verticillatus. Life Sci 70:1347-1358.

Serretti A, Artioli P (2004) From molecular biology to pharmacogenetics: a review of the literature on antidepressant treatment and suggestions of possible candidate genes. Psychopharmacology (Berl) 174:490-503.

Shopsin B, Friedman E, Gershon S (1976) Parachlorophenylalanine reversal of tranylcypromine effects in depressed patients. Arch Gen Psychiatry 33:811-819.

Stenfors C, Yu H, Ross SB (2001) Pharmacological characterisation of the decrease in 5-HT synthesis in the mouse brain evoked by the selective serotonin re-uptake inhibitor citalopram. Naunyn Schmiedebergs Arch Pharmacol 363:222-232.

Stimpson N, Agrawal N, Lewis G (2002) Randomised controlled trials investigating pharmacological and psychological interventions for treatment-refractory depression. Systematic review. Br J Psychiatry 181:284-294.

Sunal R, Gumusel B, Kayaalp SO (1994) Effect of changes in swimming area on results of "behavioral despair test." Pharmacol Biochem Behav 49:891-896.
Tanda G, Carboni E, Frau R, Di Chiara G (1994) Increase of extracellular dopamine in the prefrontal cortex: a trait of drugs with antidepressant potential? Psychopharmacology (Berl) 115:285-288.

Thase ME, Rush AJ (1995) Treatment-resistant depression. In: Psychopharmacology: the fourth generation of progress (Bloom FE, Kupfer DJ, eds). New York: Raven.

Vizi ES, Zsilla G, Caron MG, Kiss JP (2004) Uptake and release of norepinephrine by serotonergic terminals in norepinephrine transporter knockout mice: implications for the action of selective serotonin reuptake inhibitors. J Neurosci 24:7888-7894.

Wahlsten D, Rustay NR, Metten P, Crabbe JC (2003) In search of a better mouse test. Trends Neurosci 26:132-136.

Walther DJ, Peter JU, Bashammakh S, Hortnagl H, Voits M, Fink H, Bader M (2003) Synthesis of serotonin by a second tryptophan hydroxylase isoform. Science 299:76.

Wong PT, Ong YP (2001) Acute antidepressant-like and antianxiety-like effects of tryptophan in mice. Pharmacology 62:151-156.

Young SN (1991) Use of tryptophan in combination with other antidepressant treatments: a review. J Psychiatry Neurosci 16:241-246.

Young SN, Leyton M (2002) The role of serotonin in human mood and social interaction. Insight from altered tryptophan levels. Pharmacol Biochem Behav 71:857-865.

Zhang X, Beaulieu JM, Sotnikova TD, Gainetdinov RR, Caron MG (2004) Tryptophan hydroxylase-2 controls brain serotonin synthesis. Science 305:217.

Zhang X, Gainetdinov RR, Beaulieu JM, Sotnikova TD, Burch LH, Williams RB, Schwartz DA, Krishnan KR, Caron MG (2005) Loss-of-function mutation in tryptophan hydroxylase-2 identified in unipolar major depression. Neuron 45:11-16.

Zilles K, Wu J, Crusio WE, Schwegler H (2000) Water maze and radial maze learning and the density of binding sites of glutamate, GABA, and serotonin receptors in the hippocampus of inbred mouse strains. Hippocampus 10:213-225. 